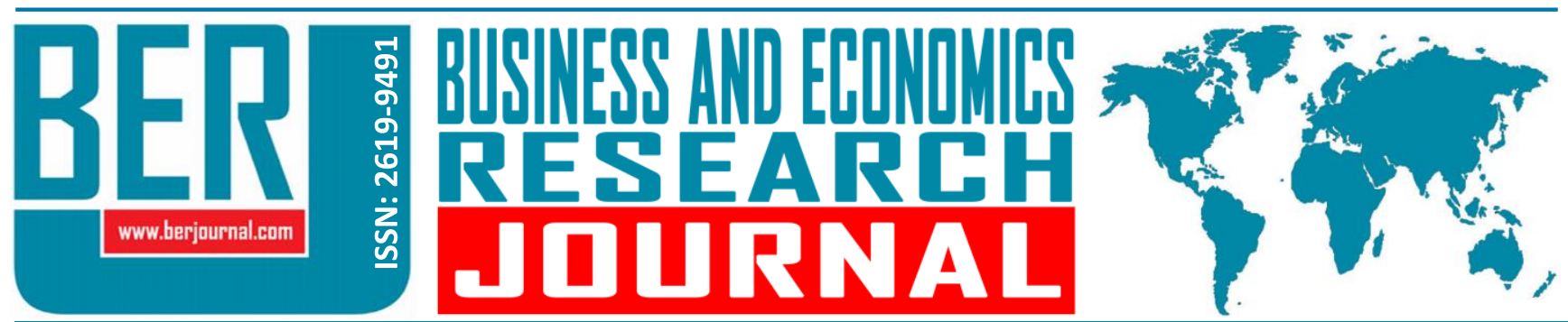

Business and Economics Research Journal Vol. 10, No. 4, 2019, pp. 929-943 doi: 10.20409/berj.2019.211

\title{
İşkolikliğin Çalışan Tutum ve Davranışları Üzerine Etkisinde İş-Yaşam Dengesinin Rolü ${ }^{1}$
}

\section{Esengul Iplik $^{\mathrm{a}}$}

Öz: Işskoliklik, gerek tanımı gerekse çalışan tutum ve davranışları üzerindeki etkisi ile ilgili yazında farklı görüşler bulunması sebebiyle son yıllarda araştırmacıların ilgisini çeken bir kavram olarak ortaya çıkmaktadır. Bu nedenle, ișkolikliğin farkı değișkenlerle ilișkilerini ortaya koyan daha fazla çalıșmanın yapılması çalışan tutum ve davranışları üzerindeki etkisinin ve buna bağlı olarak da örgütlerin işkolik çalışanlara yaklaşımlarının netleşmesi açııından önem arz etmektedir. Bu doğrultuda çalış̧manın amacı; işkoliklik ile iş-yaşam dengesi, yaşam tatmini ve duygusal bağlılık arasındaki ilişkileri ve işkolikliğin yaşam tatmini ve duygusal bağlılık üzerindeki etkisinde iş-yaşam dengesinin aracılık rolünü tespit etmektir. Bu amaç doğrultusunda kolayda örnekleme yöntemiyle seçilen 253 otomotiv sektörü çalışanından anket yoluyla veri toplanmıştır. Çalışmada kullanılan ölçeklerin yapısal geçerliğini ortaya koymak amacıyla doğrulayııı faktör analizi yapılmıs değişkenler arasındaki dolaylı ilișkiler ise yapısal eșitlik modeli ile analiz edilmiştir. Doğrulayıc faktör analizi sonucu elde edilen değerler modelin iyi uyum sağladığı ortaya konulmuştur. Değişkenler arasındaki doğrudan ve dolaylı etkileri ortaya koymak amacıyla yapılan analiz sonucunda işkolikliğin iş-yaşam dengesi, yaşam tatmini ve duygusal bağlılıkla negatif ilişkili olduğu ortaya konulmuştur. Benzer şekilde, işkolikliğin yaşam tatmini ve duygusal bağlılık üzerindeki etkisinde iş-yaşam dengesinin aracılık rolünün bulunduğu belirlenmiştir.

\section{The Role of Work-Life Balance in the Effect of Workaholism on Employee's Attitudes and Behaviors}

\begin{abstract}
Workaholism has emerged as a concept that has attracted the attention of researchers in recent years due to the fact that there are different opinions in the literature regarding both its definition and its effect on employee attitudes and behaviors. Therefore, further studies revealing the relationships of workaholic with different variables are important in terms of clarifying the impact on employee attitudes and behaviors and accordingly, the approaches of organizations to workaholic employees. In this direction the purpose of this study is to determine the relationship between workaholism, work-life balance, life satisfaction and affective commitment, and also the mediating effect of the work-life balance in relation with the impact of the workaholism on the life satisfaction and affective commitment. For this purpose, the data were collected from 253 automotive sector employees using convenience-sampling method through surveys. Confirmatory factor analysis was performed to determine the structural validity of the scales used in the study. The indirect relations between the variables were analyzed by structural equation model. The results obtained from the confirmatory factor analysis revealed that the model fits well. As a result of the path analysis conducted to reveal the direct and indirect effects between the variables, it was revealed that workaholism was negatively related to work-life balance, life satisfaction and affective commitment. Similarly, work-life balance has an intermediary role in the effect of workaholicism on life satisfaction and affective commitment.
\end{abstract}

Anahtar Sözcükler: İşkoliklik, İ̧s- Yaşam Dengesi, Yaşam Tatmini, Duygusal Bağlılık, Otomotiv Sektörü

JEL: D23, M10

$\begin{array}{ll}\text { Geliş } & : 11 \text { Nisan } 2019 \\ \text { Düzeltme } & : \text { 31 Mayıs } 2019 \\ \text { Kabul } & : 28 \text { Haziran } 2019 \\ \text { Tür } & : \text { Araştırma }\end{array}$

Keywords: Workaholism, Work-Life Balance, Life Satisfaction, Affective Commitment, Automotive Sector

JEL: D23, M10
Received : 11 April 2019

Revised : 31 May 2019

Accepted : 28 June 2019

Type : Research 


\section{Giriş}

Bireylerin ihtiyaçlarını karşılayacak bağımsız faaliyetler dizisi olarak tanımlanan iş, yaşamın sürdürülebilmesi açısından insan hayatında önemli bir unsurdur. İş, sağladığı ekonomik avantajların yanı sıra, bireylerin vakitlerinin büyük bir bölümünü harcadıkları zaman dilimi olması sebebiyle psikolojik ve sosyal ihtiyaçların karşılanması açısından da bireyin yaşamında çok önemli bir rol oynamakta ve birey açısından pozitif bir değer olarak kabul edilmektedir (Yüksel, 2014, s.120). Günümüzde teknolojide yaşanan hızlı değişim, karmaşık iş uygulamaları, rakipler arasındaki kıyasıya rekabet ve küreselleşmenin yarattığı tehdidin beraberinde getirdiği işin doğasındaki değişime bağlı olarak, çalışanların iş yapma şekilleri de değişmektedir. Yaşanan bu hızlı ve çok yönlü değişim, çalışanların iş yaşamında daha fazla sorunla karşı karşıya kalmasına ve ulusal ve uluslararası pazarda tipik çalışma saatlerinin genişlemesine yol açmaktadır. Çalışma sürelerinin uzaması ise işin bazı insanlar için hayatlarının odağı haline gelmesine ve fazla çalışmaya eğilimli çalışanların işkolik olma potansiyellerinin artmasına neden olmaktadır.

Çalışanların iş yapma alışkanlıklarını düzenleyememesi ve diğer yaşam faaliyetlerinin çoğunu ihmal etmesine neden olacak kadar çok çalışması şeklinde kendini gösteren obsesif-kompulsif bir bozukluk şeklinde tanımlanan (Robinson, 2007: 7) işkoliklik, ilk başlarda çok çalışmakla veya işe bağlılıkla aynı anlamda kullanılmasına ve olumlu bir durum olarak değerlendirilmesine rağmen, yapılan sonraki çalışmalarda farkı bakış açılarıyla ele alınmıştır. Dolayısıyla bugüne kadar yapılan çalışmalarda, işkolikliğin iyi mi yoksa kötü bir durum mu olduğuna ilişkin farklı yaklaşımlar ortaya atılmıştır. Bazı araştırmacılar (Machlowitz, 1978; Scott, Moore ve Miceli, 1997; Peiperl ve Jones, 2001), işkolikliği olumlu bir durum olarak nitelendirmekte ve işkoliklerin tatmin düzeyinin, yaratıcılıklarının ve performanslarının daha yüksek olması sebebiyle, işkolikliğin örgüt açısından olumlu sonuçlar doğuracağını ileri sürmektedirler. Buna karşın bazı araştırmacılar (Spence ve Robbins, 1992; Porter, 1996) ise işkolikliğin alkolizme benzer bir tür bağımlılık olduğu, uzun vadede hem bireyin kendisine hem de örgüte zarar vereceği ve işkolikler açısından aşırı çalışma ihtiyacının, sağlıklarını tehlikeye soktuğu, mutluluklarını azalttığı, kişilerarası ilişkileri ve sosyal işlevselliklerini kötüleştirdiği için olumsuz bir durum olarak nitelendirmektedir. Bu araştırmacılar tarafından yapılan çalışmalar, işkolik bireylerin zamanla sağlıklarının ve uyku düzenlerinin bozulabildiğini, stres düzeylerinin arttı̆̆ını ve bunlara bağlı olarak da iş dışı yaşamlarında düzensizlikler meydana gelebilirken, iş yaşamlarında ise verimlilik ve etkinliklerinin gittikçe azalabildiğini ortaya koymaktadırlar. Yazında yer alan bu görüş farklııkları, örgütlerin işkoliklik çalışanlara nasıl yaklaşması gerektiği yönünde çelişkiler ortaya çıkmasına neden olmaktadır (Ölçer, 2005: 125). Bu bağlamda, çalışanların birtakım içsel veya dışsal nedenlerden dolayı işlerine karşı aşırı bağımlı olma eğilimi olarak tanımlanan ve bireylerin gerek iş gerekse iş dışı yaşamlarını etkileyen bir olgu olan işkolikliğin farklı çalışan tutum ve davranışlarıyla ilişkisini ortaya koyan daha fazla çalışmanın yapılması örgütlerin işkolik çalışanlara yönelik yaklaşımlarının şekillenmesi açısından önem arz etmektedir. Bu doğrultuda, bu çalışma ile uzun vadede örgüte zarar verebilen bir unsur olan işkolikliğin iş-yaşam dengesi, yaşam tatmini ve örgüte duygusal bağlılık gibi çalışan tutum ve davranışlarıyla olan ilişkisi ile işkolikliğin yaşam tatmini ve duygusal bağlılık üzerindeki etkisinde iş-yaşam dengesinin aracılık rolünün belirlenmesi amaçlanmaktadır.

\section{Kuramsal Çerçeve}

\section{1. İşkoliklik}

"iş̧oliklik" terimi akademik yazında ilk kez 1970li yılların başında ele alınmış ve zorunlu ya da kontrol edilemeyen bir şekilde sürekli çalışma ihtiyacı şeklinde tanımlanmıştır. Bu ilk tanım, daha sonraki birçok işkoliklik tanımında vurgulanan aşırı derecede çok çalışmak ve güçlü, karşı konulamaz bir içsel dürtünün varlığı gibi iki temel unsuru kapsamaktadır. Bu unsurlardan birincisi, işkoliklerin iş için olağanüstü bir zaman ayırma eğiliminde olduklarına ve örgütsel veya ekonomik gereksinimleri karşılamak için makul kabul edilen zamanın ötesinde çalıştıklarına işaret etmektedir. İkincisi ise, işkoliklerin çalışmadıklarında bile, sürekli olarak işlerini düşündüklerini, yani, işkoliklerin çalışmayı saplantı haline getirdiğini göstermektedir. Aslında, işkolikliğin sırasıyla, davranışsal ve bilişsel yönünü temsil eden bu iki unsur, alkolizmde olduğu gibi bir tür bağımlılı̆̆ ifade etmektedir (Schaufeli, Taris ve Van Rhenen, 2008: 175). 
Bireyin içten gelen bir dürtüyle çalışmaya takıntılı olması şeklinde tanımlanan (Schaufeli, Shimazu ve Taris, 2009b: 322) işkoliklik, bugüne kadar yapılan çalışmalarda farklı bakış açılarıyla ele alınmış ve farkı şekillerde tanımlanmıştır. Örneğin, ilk başlarda, işkolik basitçe haftada en az 50 saat çalışma şeklinde tanımlanırken, Machlowitz (1978), işkolikleri diğerlerinden ayıran şeyin, çalışma saatleri değil, işe karşı tutumları olduğunu belirtmiştir. Spence ve Robbins (1992) ise, işkolikliği aşırı derecede işe bağlı olma, içsel baskılardan dolayı sürekli kendini çalışmak zorunda hissetmek ve işinden düşük düzeyde zevk alma şeklinde tanımlamışlardır.

Son yıllarda, çok uzun saatler çalışan veya çok sıkı çalışan insanları tanımlarken kullanılan popüler bir kavram haline gelen işkolikliği, tanımlarken aşırı çalışmanın nedenlerini açıklamak gerekmektedir. Finansal zorunluluk, örgüt kültürü ve hatta bireyin evliliğinde yaşadığı sorunlar gibi aşırı çalışma saatlerine katkıda bulunabilecek sayısız dış etken bulunmaktadır. Literatürde, işkoliklerin diğer çalışanlardan farklı olarak, finansal intiyaçlar gibi dış koşullardan ziyade, içsel bir dürtüyü veya intiyacı karşılamak için fazla çalışma eğiliminde oldukları konusunda bir fikir birliği vardır (Mirza, 2012: 3-4). Scott vd. (1997), iş ile ilgili faaliyetlere gönüllü olarak fazla zaman harcamanın, işkolikliğin temel unsurlarından biri olduğunu belirtmişlerdir. İşkolik çalışanlar yaptıkları işlerde aşırı zaman harcamakta, meslektaşlarından ve örgütsel veya ekonomik standartları karşılamak için olması gerekenden daha fazla çalışmakta, çalışmıyorken bile sürekli işlerini düşünmekte, çalışmayı bırakamamakta ve bırakmayı da istememektedirler. Çok çalışmak için güçlü ve kontrol edilemeyen içsel bir dürtü yaşamaktadırlar (van Beek, Taris ve Schaufeli, 2011: 469).

İşkoliklik genel olarak tek boyutlu bir kavram olarak değil, çeşitli alt kavramlardan oluşan karmaşık ve çok yönlü bir yapı olarak kabul edilmektedir. Her biri kendine özgü öncüllere ve sonuçlara sahip olan çeşitli türde işkoliklik davranışı bulunmaktadır (Buelens ve Poelmans, 2004: 441). Buna göre, Spence ve Robins (1992) işkolikliğin aşırı işe bağııık, işe yönelme ve düşük iş hazzı olmak üzere üç faktörden oluştuğunu ileri sürmüşlerdir. İşe bağlııı, bireylerin zamanlarının (hem iş hem de iş dışı) ne kadarını işe ayırdıklarını ve kendilerini ne ölçüde verimli bir şekilde çalışmaya adadıklarını ifade ederken; işe yönelme, kişinin çalışmak için sahip olduğu içsel motivasyonunu, iş hazzı ise, bireylerin çalışmaktan zevk alma derecesini ifade etmektedir. İşkoliklikle ilgi diğer bir sınıflandırmayı yapan Schaufeli, Taris ve Bakker (2006) ise, işkolikliği, aşırı çalışmak ve kompolsif (zorla) çalışma olmak üzere iki boyutlu bir yapı olarak ele almışlardır. Aşırı çalışmak, çalışma faaliyetlerine olağanüstü zaman ayırma şeklinde ortaya çıkan davranışsal bir eğilim olarak tanımlanırken; işkolikliğin bilişsel bileşeni olan zorla çalışma ise çalışmayı takıntı haline getirme eğilimi olarak tanımlanmaktadır (Schaufeli, Bakker, van der Heijden ve Prins, 2009a: 175).

Literatürde işkolikliğin çalışan tutum ve davranışlarıyla ilişkisini inceleyen çalışmalarda işkoliklik esas olarak olumsuz sonuçlarla ilişkilendirilmektedir (van Beek vd., 2011: 469). Buna göre, işkolik çalışanlar iş yerinde daha fazla kişilerarası çatışma yaşamakta (Mudrack, 2006), işlerinden daha az tatmin olmakta (Burke ve MacDermid, 1999), daha fazla iş-aile çatışması yaşamakta (Taris, Schaufeli ve Verhoeven, 2005; Schaufeli vd., 2009b) ve iş dışında zayıf sosyal ilişkiler kurabilmektedir (Robinson, 2007; Schaufeli vd., 2008).

\section{2. İş-Yaşam Dengesi}

İş ve aile bireyin yaşamının merkezindeki en önemli iki unsurdur. İş ve aile aktiviteleri sıklıkla farklı zamanlarda ve yerlerde meydana geldiğinden hem iş hem de aile yaşamında birçok sorumluluk üstlenen bireyler için, bu iki alan arasında dengeleme, son yıllarda büyük bir yaşam sorunu haline gelmeye başlamıştır. Hem iş hayatında hem de ailede önemli sorumlulukları olan bireylerin sayısındaki dikkat çekici artış sonucu araştırmacıların ilgisini çekmeye başlayan bir kavram olan iş-yaşam dengesi, bireyin yaşamındaki rollerinin ne denli dengeli olduğuna dair algıları diğer bir deyişle iş ve iş dışı yaşamda üstlenmiş oldukları roller arasında düşük rol çatışması algılamaları şeklinde tanımlanmaktadır (Clark, 2001: 349).

Iş-yaşam dengesini, yaşam kalitesini belirleyen bir faktör olarak kavramsallaştıran Greenhaus, Collins ve Shaw (2003), dengenin var olabilmesi için iş rolündeki deneyimler ile aile rolündeki deneyimler arasındaki eşitliğe vurgu yapmaktadırlar. Bu doğrultuda, iş-yaşam dengesini, bir bireyin iş ve iş dışı yaşamındaki rollerine eşit katılım sağlayabilme ve bu rollerinden eşit derecede tatmin olabilme derecesi olarak tanımlamakta ve işaile dengesinin zaman dengesi, katılım dengesi ve tatmin dengesi olmak üzere üç bileşeni olduğunu ileri 
sürmektedirler. Zaman dengesi, işe ve aile rollerine eşit süre ayrılması şeklinde tanımlanırken; katılım dengesi: iş ve aile rollerinde eşit düzeyde psikolojik katılımı; tatmin dengesi ise, iş ve aile rollerinden eşit düzeyde tatmin olmayı ifade etmektedir. Buna göre, iş-yaşam dengesinin her bileşeni, zaman, katılım veya tatmin düzeylerinin eşit derecede yüksek veya eşit derecede düşük olmasına bağlı olarak pozitif dengeyi veya negatif dengeyi yansitabilmektedir (Greenhaus vd., 2003: 513).

İs ve iş dışı yaşam arasındaki dengenin anlaşılmasına yönelik farklı teorik yaklaşımlar bulunmaktadır. Bazı çalışmalarda (Clark 2001; Saltzstein, Ting ve Saltzstein 2001; Premeaux, Adkins ve Mossholder, 2007), denge çatışmanın yokluğuyla ilişkilendirilmekte ve iş ile iş dışı yaşamları arasında düşük düzeyde çatışma yaşayan çalışanların, daha fazla çatışmaya sahip olanlara kıyasla daha iyi bir dengeye sahip olacakları belirtilmektedir. Buna karşılık, bazı çalışmalarda ise iş ve iş dışı yaşam arasında çatışmadan ziyade zenginleşmenin olmasının, dengenin sağlanması anlamına geldiği; sonuç olarak zenginleşmenin, çatışmanın olumsuz etkilerini ortadan kaldırdığı ve dengeye yol açtığı ileri sürülmektedir (Haar, 2013: 3307).

\subsection{Duygusal Bağlılık}

Çalışanlar ve örgüt arasındaki ilişkiyi yansıtan psikolojik bir kavram (Sayğan, 2011: 1310) olan örgütsel bağ|ıık, birçok çalışan tutumunun önemli belirleyicilerinden biri olması sebebiyle hem uygulayıcıların hem de örgütsel psikoloji alanında çalışan akademisyenlerin en fazla odaklandığı konulardan bir tanesi olarak ortaya çıkmaktadır. Örgütsel bağlılık genel anlamda çalışanın çalıştığı örgüte karşı bağlıık ve sadakat duygusu olarak tanımlanmaktadır. Çalışanlar, örgütün hedefleri ile uyumlu olduğunda, örgüt adına çaba sarf etmeye istekli olduklarında ve örgütle ilişkilerini sürdürmek istediklerinde organizasyona bağlı oldukları söylenebilmektedir (Kessler, 2013: 526).

Literatürde örgütsel bağlılıkla ilgili iki hakim görüş bulunmaktadır. Bunlardan birincisi, bağlılığı duygusal veya tutumsal olarak görmekte ve örgütsel davranış veya psikoloji yaklaşımı olarak adlandırılmaktadır. Bu görüş, bireyi örgütle özdeşleşmiş ve bu nedenle, hedeflerine ulaşmak için örgütte çalışmayı sürdürmeye kendini adamış (bağlı) olarak görmektedir. Bağlııı̆ın bu şekli duygusal bağlılık ve değer bağlılığı olarak ifade edilmektedir. Bağlılıkla ilgili ikinci görüş ise, Becker (1960) tarafından ortaya atılan yan bahis (side-bet) teorisine dayanmaktadır. Bu yaklaşımın temel unsuru, bireyin geçmişte yaşadığı olayların, mevcut zamanda karar alırken bir takım maliyetlere veya hak kaybı gibi sonuçlara yol açabildiği ve bunun da karar verme konusundaki seçeneklerini kısıtlayacağı iddiasıdır. Becker (1960)'a göre, birey örgütte çalışmayı sürdürdükçe, belirli bir süre sonra, istikrarlı devam eden faaliyetlerden, yani örgütte çalışmayı sürdürmekten vazgeçmesini zorlaştıran bazı maliyetler ortaya çıkabilmektedir. Yani, uzun bir süre istikrarlı bir şekilde aynı şeyi yapmanın etkisi, bir faaliyeti devam ettirmemenin maliyetini arttırmaktır. Dolayısıyla örgütte uzun süre çalışmak bir kişinin harcadığı zaman ve çaba gibi yatıımları arttırmakta; bu nedenle de, ayrılma maliyetleri daha yüksek örgütsel bağlılık düzeyine yol açabilmektedir (Cohen, 1993: 144-145). Meyer ve Allen (1991), Becker (1960) tarafından tanımlanan bu bağlılık türünü devam (maliyet temelli) bağlılığı olarak nitelendirmiş ve buna duygusal (istek-temelli) ile normatif (zorunluluk temelli) bağlıı̆̆ı dahil ederek üç bileşenli bağılıı modelini geliştirmişlerdir (Powell ve Meyer, 2004: 158).

Örgütsel bağ|ılığın boyutlarından biri olan devam bağ|ılığı, bireyin çalıştığı örgütten ayrılma ile ilgili maliyetler konusundaki farkındalı̆̆ını ifade etmektedir. Çalıştığı örgütle bağlantısının temeli devam bağ|ıı̆ına dayanan çalışanlar, örgütten ayrılmanın maliyeti yüksek olması gibi nedenlerle kendilerini bunu yapmak zorunda hissettikleri için örgütte çalışmaya devam etmektedirler. Diğer bir bağlılık boyutu olan normatif bağ|ıık, örgütte çalışmaya devam etme yükümlülüğünü yansıtmaktadır. Yüksek düzeyde normatif bağlıığı olan çalışanlar, daha iyi bir iş alternatifi olmadığı için örgütte kalmaları gerektiğini düşünmekte, bu nedenle de örgütten ayrılmamaktadırlar. Son olarak örgüte duygusal bağlıık ise, çalışanın duygusal olarak örgüte bağıı olması, onunla bütünleşmesi ve örgütün amaçlarıyla özdeşleşmesi şeklinde tanımlanmaktadır. Güçlü bir duygusal bağlıığa sahip çalışanlar yalnızca istedikleri için örgütte çalışmaya devam etmektedirler (Meyer ve Allen, 1991: 67).

Birey bir örgütte çalışmaya başladığında ilk etapta araçsal ve duygusal bağlılık olmak üzere iki tür bağııık ortaya çıkmaktadır. Ancak bu ilk aşamalarda baskın olan çoğunlukla kişinin örgüte yaptığı katkılar ve 
aldığı ödüller arasındaki maddi değişimin kalitesini algılamasından kaynaklanan bir bağlıık olarak tanımlanan araçsal bağlılıktır. Birey örgütte zaman geçirdikçe, örgütle ilgili daha fazla bilgiye sahip oldukça ve örgütü daha iyi tanıdıkça, daha derin bir bağlılık düzeyi olan ve örgütle özdeşleşme, aidiyet, duygusal bağlanma gibi duygularla tanımlanan duygusal bağlılık ortaya çıkmaya başlamaktadır. Duygusal bağlılık, daha yavaş ve genellikle araçsal bağlılıktan daha sonra gelişmekte, ancak daha derin bir psikolojik bağlanmayı vurgulamaktadır. Bu nedenle, duygusal bağ|ııı, çalışanların kendini örgütle özdeşleştirdiği, duygusal olarak bağlandığı ve güçlü bir aidiyet duygusu yaşadığı güçlü bir psikolojik bağlılı̆̆ı ifade etmektedir (Ghosh, 2014: 9).

Çalışanların duygusal bağılıı̆ını etkileyen birçok faktör bulunmaktadır. Bu faktörleri genel olarak kişisel özellikler ve iş deneyimleri şeklinde sınıflandırılabilmektedir. Buna göre başarma ihtiyacı, özerklik, bireysel iş ahlakı, kontrol odağı ve işini yaşamının merkezine alması gibi kişisel eğilimler çalışanın örgüte karşı duygusal bağlı olma eğilimini arttırmaktadır (Meyer ve Allen, 1991: 69). Duygusal bağlılık, temel olarak, kişisel eğilimlerin yanı sıra iş tatmini ve örgütsel adalet gibi olumlu iş deneyimleri sonucu da ortaya çıkmaktadır. Örgüte duygusal bağlıığı yüksek olan kişi kendini çalıştığı örgütle özdeşleştirmekte ve örgütün üyesi olmaktan mutluluk duymaktadırlar. Örgütleriyle özdeşleşme düzeyleri yüksek çalışanlar da örgütlerine aidiyet duygusu geliştirmekte ve bu da örgüt açısından olumlu birçok çalışan tutum ve davranışının ortaya çıkmasına yol açmaktadır. Buna göre duygusal bağlılık, yüksek çalışan performansı ve örgütsel vatandaşlık davranışları gibi arzu edilen sonuçlarla olumlu, buna karşıık işe geç gelme ve devamsızlık gibi olumsuz çalışan davranışlarıyla ise negatif ilişkilidir (Wasti, 2002: 526).

\subsection{Yaşam Tatmini}

Pozitif ve negatif duygulanım ile birlikte öznel iyi oluşun bileşenlerinden birisi olan ve bilişsel boyutunu oluşturan yaşam tatmini Shin ve Johnson (1978: 478) tarafından, bireyin kendi yaşamı ile ilgili belirlemiş olduğu bir takım kriterlere dayanarak yaşam kalitesini değerlendirmesi ve bunun sonucunda ortaya çıkan bilişsel ve yargısal algıları olarak tanımlanmaktadır. Bu tanıma göre tatmin algısı, bireyin mevcut durumunu uygun bir standart ile karşılaştırmasına bağlıdır ve bireyler şu anki durumlarından ne kadar memnun olduklarına ilişkin kararı dışarıdan dayatılan standartlara göre değil kendi belirlediği standartlara bağlı olarak vermektedirler (Diener, Emmons, Larsen ve Grifin, 1985: 71).

Öznel iyi oluş konusuna olan ilgi felsefe ve psikolojide uzun bir geçmişe sahip olmasına rağmen, mutluluk ve yaşam tatmini konuları birçok disiplin tarafından nispeten daha yakın zamanda incelenmeye başlanmıştır. Örgütsel davranış alanında da yaşam tatmini kavramı, bireyin yaşamının farklı alanlarında (örn., iş, aile, boş zaman) yaşadığı tatminin, yaşamla ilgili genel tatminini doğrudan etkileyeceği düşüncesine dayanarak birçok araştırmacı tarafından ele alınmaktadır (Near, 1984: 351). Bireyin yaşamının farkı alanlarından birinde yaşadığı deneyimin yaşamının diğer alanların da etkileyebileceğini öne süren yayılma teorisine (Heller, Judge ve Watson, 2002, s.816) dayanarak bir işin genel yaşam tatmini üzerinde çeşitli şekillerde önemli etkileri olduğu varsayılmaktadır. Dolayısıyla, insanların ihtiyaçlarını ve isteklerini karşılamalarına yarayan gelir kaynağı olan iş çoğu insanın gününün büyük bir kısmını geçirdiği bir alandır ve işyerinde meydana gelen değişiklikler yaşam kalitesini iyileştirmekte ve yaşam tatminini arttırmaktadır (Demerouti, Bakker, Nachreiner ve Schaufeli, 2000: 456).

Bireyin yaşam kalitesinin öznel bir ifadesi olan yaşam tatminini etkileyen birçok faktör bulunmaktadır. Yaşam tatminini etkileyen değişkenleri genel olarak bireysel ve işle ilgili değişkenler şeklinde sınıflandırmak mümkündür. Buna göre, bireyin sahip olduğu kişilik özellikleri (nevrotiklik, dışa dönüklük, sorumluluk gibi) yaşam tatmini üzerinde etkili olan bireysel değişkenlerden bir tanesidir (Schimmack, Diener ve Oishi, 2002; Hayes ve Joseph, 2003). Bunun dışında cinsiyet, yaş, gelir ve eğitim düzeyi gibi bireyin demografik özellikleri de yaşam tatmini algısı ile önemli ölçüde ilişkili olan diğer bireysel değişkenlerdir (Melèndez, Tomás, Oliver ve Navarro, 2009). Bireyin yaşam tatmini algısı üzerinde etkili olan işle ilgili değişkenler ise, iş tatmini (Iverson ve Maguire, 2000), örgütsel bağlılık (Vanaki ve Vagharseyyedin, 2009), rol belirsizliği ve rol çatışması (Pasupuleti, Allen, Lambert ve Cluse-Tolar, 2009), tükenmişlik (Anand ve Arora, 2009) ile destek algısı (Dixon ve Sagas, 2007) şeklinde sınıflandırılmaktadır (İplik, 2017). 


\section{5. İşkoliklik, İş-Yaşam Dengesi, Yaşam Tatmini ve Duygusal Bağlıık Arasındaki İlişkiler}

Çalışma faaliyetlerine olağanüstü zaman ayırılması şeklinde ortaya çıkan davranışsal bir eğilim ve çalışma takıntısı ile ifade edilen işkoliklik, bazı çalışmalarda, bireyin iş dışındaki diğer ilgi alanlarını ihmal etmesine ve olumsuz sonuçlara yol açan yoğun bir çalışma dürtüsüyle nitelendirilen bir bağımlılık olarak kavramsallaştırılmıştır (Aziz, Uhrich, Wuensch, ve Swords, 2013: 71). İşkolikler iş tanımlarının gerektirdiğinden daha fazla çalışmakta ve birlikte çalıştıkları arkadaşlarının ya da yöneticilerinin beklediğinden çok daha fazla çaba sarf etmekte ve bunu yaparken de iş dışındaki hayatlarını ihmal etmekte ve iş-yaşam dengeleri bozulabilmektedir (Schaufeli vd., 2008: 175). Yapılan çalışmaların (Aziz ve Zickar, 2006; Aziz, Adkins, Walker ve Wuensch, 2010; Pekdemir ve Koçoğlu, 2014) sonuçları da işkoliklik ile iş-yaşam dengesi arasındaki negatif ilişkiyi ortaya koymaktadır. Yapılan önceki çalışmalardan hareketle işkoliklik-işyaşam dengesi ilişkisine ilişkin geliştirilen hipotez şu şekildedir:

\section{$\mathbf{H}_{1}$ : İşkoliklik ile iş-yaşam dengesi arasında negatif yönlü bir ilişki vardır.}

İşkoliklerde memnuniyet sadece işten kaynaklanırken, diğer yaşam alanları (örn. aile, boş zaman etkinlikleri, ilişkiler) ihmal edilmektedir. Aşırı çalışma, obsesif-kompulsif eğilimler de dahil olmak üzere, bir bağımlılık sonucu ortaya çıkması sebebiyle, çalışma gereksiniminin artması, bireyin farklı yaşam alanlarındaki rollerini yerine getirmesini engellemekte (Aziz vd., 2013: 71), bu da bireyin yaşam kalitesi algısını dolayısıyla da yaşam tatminini olumsuz etkilemektedir. Yapılan çalışmalar (Levy; 2015; Bulgurcu Gürel ve Altunoğlu, 2016; Vitiello, Aziz ve Wuensch, 2016) da işkoliklik ile genel yaşam tatmini arasındaki negatif ilişkiyi ortaya koymaktadır. Yapılan önceki çalışmalardan hareketle işkoliklik-yaşam tatmini ilişkisine ilişkin geliştirilen hipotez şu şekildedir:

$\mathbf{H}_{2}$ : İşkoliklik ile yaşam tatmini arasında negatif yönlü bir ilişki vardır.

İşkoliklik bazen basitçe örgüte aşırı derecede bağlılık veya bunun bir yönü olarak görülmüştür. Ancak işkoliklik birçok açıdan duygusal bağılııtan farklı bir kavramdır. Buna göre, işkoliklik ve duygusal bağlılık arasındaki kritik ayrım, işkoliklik aşııı çalışma davranışıyla tanımlanırken, bağııı̆ın çalışma davranışı açısından tanımlanmayıp doğası gereği duyuşsal olması ve işe harcanan gönüllü zamanı içermemesidir. Aksine duygusal bağlılık, işveren ve diğer durumsal faktörlere göre değişen bir tepkidir. Buna karşılık, işkolikler, belirli bir örgüt veya iş hakkındaki duygulara bakmaksızın, çeşitli ortamlarda ekstra çaba sarf etmektedirler. Yani duygusal bağ|ılık olumlu çalışma deneyimleri ile artıp, bireyin çalıştığı örgüte bağlı olarak değişirken, işkoliklerin içsel çalışma dürtüsü çalıştıkları örgüte bağlı olmaksızın ortaya çıkmaktadır. İşkolikliğin iş tatmini, örgütsel bağııık gibi olumlu çalışan tutum ve davranışlarıyla ilişkisi işkolik davranışın türüne bağlı olarak değişmektedir. Eğer birey kendini çalışmaya zorunlu hissettiği için ya da işe bağımlılık sonucu işkolik davranış sergiliyorsa, işkoliklik iş ve yaşam tatmini, performans gibi çalışan tutum ve davranışlarını olumsuz etkilemektedir. Ancak işkolik davranış, bireyin tamamen başarı odaklı olması nedeniyle ortaya çıkıyorsa, yani birey kendini zorunlu hissettiği ya da çalışmaya takıntılı olduğu için değil tamamen başarı elde etme güdüsüyle işkolik davranış sergiliyorsa, işkoliklik olumlu bir olgu olarak değerlendirilmektedir. Bu durumda örgüte bağılık, işkoliklik davranışının bir sonucu olarak ortaya çıkabilmektedir (Scott vd., 1997, s.300-306; Schaufeli vd, 2008). İ̧solikliğin iş tatmini ve örgütsel bağlılık gibi çalışan tutumlarıyla ilişkisini inceleyen bazı çalışmalarda (Rakhshanimehr ve Jenaabadi, 2015; Arsezen ve Kılıçarslan, 2017) işkoliklik ile iş tatmini ve bağlılığın boyutlarından duygusal bağ|ılık arasında zayıf bir pozitif ilişkinin var olduğu, bağlılığın diğer iki boyutuyla ise anlamlı ilişkilerin olmadığı görülmektedir. Bu nedenle bu çalışma kapsamında işkoliklik ile bağlılığın boyutlarından duygusal bağııık ele alınmış ve buradan hareketle işkoliklik-duygusal bağııık ilişkisine ilişkin geliştirilen hipotez şu şekildedir:

\section{$\mathbf{H}_{3}$ : İ̧soliklik ile duygusal bağılık arasında pozitif yönlü bir ilişki vardır.}

Bireyin yaşamının farklı alanlarındaki rolleri arasındaki etkileşimi ifade eden iş-yaşam dengesi, çalışanın refahı ve üretkenliği üzerinde önemli etkilere sahiptir. Birçok araştırmacı, bireyin iş ve iş dışı yaşamındaki verimliliğini önemli ölçüde etkileyen psikolojik iyi oluşu ve yaşamdaki genel uyum duygusuyla ilişkili olduğu için işteki ve aile içindeki rol arasındaki dengenin bir göstergesi olan iş-yaşam dengesini incelenmesi gereken önemli konulardan bir tanesi olarak kabul etmektedir. İş-yaşam dengesi yaşayan bireyler 
yaşamlarının tüm alanlarındaki kendilerine özgü rol faaliyetlerini yerine getirebildikleri için yaşam kaliteleri artmakta ve böylece işlerinden ve yaşamlarından daha fazla tatmin olmaktadırlar (Greenhaus, vd., 2003: 515). İş-yaşam dengesinin çalışanlar üzerindeki etkileri ile ilgili olarak yapılan araştırmalar (Gorsy ve Panwar, 2016; Azeez, Fapohunda, ve Jayeoba, 2017; Sakthivel ve Jayakrishnan, 2018) iş ve yaşam rolleri arasında dengeyi algılayan kişilerin yaşamlarından memnun olduklarını, psikolojik ve fiziksel sağlıklarının daha iyi olduğunu ortaya koymaktadır. İş-yaşam dengesi, ayrıca, çalışanın iş tatminini, örgüte duygusal bağılığını, örgütsel vatandaşlık davranışını ve performansını arttırmak, devamsızık düzeyini ve işgücü devir hızını azaltmak gibi olumlu birçok etkiye de yol açabilmektedir. Yapılan önceki çalışmalardan hareketle iş-yaşam dengesi ile yaşam tatmini ve duygusal bağlılık ilişkisine ilişkin geliştirilen hipotezler şu şekildedir:

$\mathbf{H}_{4}$ : İş-yaşam dengesi ile yaşam tatmini arasında pozitif yönlü bir ilişki vardır.

$\mathbf{H}_{5}$ : İş-yaşam dengesi ile duygusal bağlııı arasında pozitif yönlü bir ilişki vardır.

Bu çalışmada işkolikliğin çalışanların yaşam tatmini ve örgüte duygusal bağlılıkları üzerindeki doğrudan etkileri ile iş-yaşam dengesi aracılığıyla dolaylı etkisinin de incelenmesi söz konusudur. Yapılan çalışmalar işkoliklik ile çalışanların yaşam tatmini ve duygusal bağılıkları arasında ilişki olduğunu ortaya koymaktadır. Benzer şekilde yapılan çalışmalarda iş-yaşam dengesi yaşam tatmini ve duygusal bağlılık arasında da doğrudan bir ilişki olduğu ve bireylerin iş ve iş dışı yaşamları arasında denge olduğunu algılamaları durumunda yaşam tatmin düzeyleri ile duygusal bağlılıklarının de arttı̆̆ı belirtilmektedir. Söz konusu değişkenler arasında doğrudan ilişkilerin olması, iş-yaşam dengesinin işkoliklik ile yaşam tatmini ve işkoliklik ile duygusal bağlııı arasındaki ilişkilerde dolaylı etkilerinin de olabileceğine işaret etmektedir.

$\mathbf{H}_{6}$ : İşkolikliğin yaşam tatminine etkisinde iş-yaşam dengesinin aracılık rolü vardır.

$\mathbf{H}_{7}$ : İşkolikliğin duygusal bağılıı̆a etkisinde iş-yaşam dengesinin aracılık rolü vardır.

Yapılan literatür taraması sonucu geliştirilen hipotezlere bağı olarak aşağıda yer alan araştırma modeli oluşturulmuştur.

Şekil 1. Araştırma Modeli

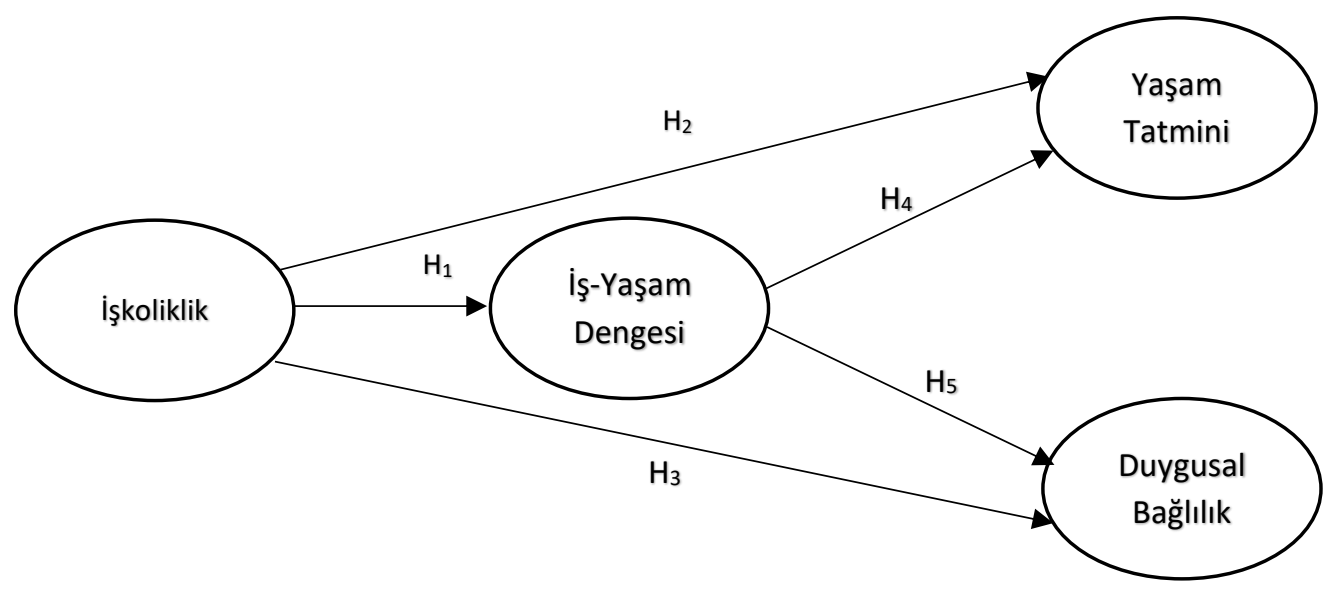

\section{Yöntem}

\section{1. Örneklem}

İ̧kolikliğin yaşam tatmini ve duygusal bağlıık gibi çalışan tutumlarına etkisinde iş-yaşam dengesinin aracılık rolünün ortaya konulmasının amaçlandığı bu çalışmada kullanılan veri kolayda örnekleme yöntemi kullanılarak Adana ilinde otomotiv sektöründe faaliyet gösteren firmaların çalışanlarından toplanmıştır. Çalışma kapsamında toplam 300 anket dağıtılmış olup, bu anketlerden 260 adedi geri dönmüş ve 7'si hatalı doldurulması sebebiyle çalışma 
dışında bırakıımıştır. Böylece analizde kullanılan toplam anket sayısı 253 olmuştur. Anketi cevaplayan bireylere ilişkin demografik veriler Tablo 1'de yer almaktadır.

Tablo 1. Örnekleme illişkin Demografik Veriler

\begin{tabular}{|c|c|c|c|c|c|}
\hline Cinsiyet & $\mathbf{F}$ & $\%$ & Eğitim Durumu & $\mathbf{F}$ & $\%$ \\
\hline Kadın & 108 & 42,7 & illkokul & 15 & 5,9 \\
\hline Erkek & 145 & 57,3 & Lise & 101 & 39,9 \\
\hline \multirow[t]{4}{*}{ Toplam } & 253 & 100,0 & Önlisans & 44 & 17,4 \\
\hline & & & Lisans & 84 & 33,2 \\
\hline & & & Lisansüstü & 9 & 3,6 \\
\hline & & & Toplam & 253 & 100,0 \\
\hline Yaş & $\mathbf{F}$ & $\%$ & Çalışma Süresi & $\mathbf{F}$ & $\%$ \\
\hline 20 ve altı & 11 & 4,3 & 1 yıldan az & 19 & 7,5 \\
\hline $21-30$ & 94 & 37,2 & $1-5$ yıl & 107 & 42,3 \\
\hline $31-40$ & 86 & 34,0 & 6-10 yıl & 76 & 30,0 \\
\hline $41-50$ & 47 & 18,6 & $11-15$ yıl & 26 & 10,3 \\
\hline $51-60$ & 15 & 5,9 & $16-20$ yıl & 15 & 5,9 \\
\hline \multirow[t]{2}{*}{ Toplam } & 253 & 100,0 & 21 yıl üzeri & 10 & 4,0 \\
\hline & & & Toplam & 253 & 100,0 \\
\hline
\end{tabular}

Çalışma kapsamında analize tabi tutulan anketleri yanıtlayan katılımcıların \%57,3'ü erkek, \%42,7'si kadınlardan oluştuğu görülmektedir. Örneklemin eğitim durumu incelendiğinde ise, katılımcıların \%39,9'u lise, \%33,2'si lisans, \%17,4'ü önlisans, \%5,9'u ilkokul ve \%3,6'sı ise lisansüstü mezunudur. Söz konusu örneklemin yaş ortalaması 33,2 (SS: 8,66) olarak belirlenirken, ortalama çalışma süresi ise 6,31 (SS: 5,59) olarak tespit edilmiştir.

\section{2. Ölçüm Araçları}

Anket yöntemi kullanılarak veri elde etme yoluna gidilen çalışmada, çalışanların işkoliklik, iş-yaşam dengesi, yaşam tatmini ve duygusal bağlılıklarını ölçmek için literatürde yer alan ve en uygun olduğu düşünülen ölçekler belirlenerek anket formu oluşturulmuştur. Ankette yer alan ifadeler $5^{\prime} l i$ Likert ölçeği kullanılarak düzenlenmiştir. Soru formunda işkoliklik, iş-yaşam dengesi, yaşam tatmini ve duygusal bağıılığa yönelik ifadelerin yanında katılımcıların cinsiyet, yaş, eğitim durumu, çalışma süresine ilişkin demografik sorulara da yer verilmiştir.

işkoliklik: Çalışmada işkolikliği ölçmek için Schaufeli vd. (2006) tarafından geliştirilen DUWAS (Dutch Work Addiction Scale) ölçeğinin kısa formu kullanılmıştır. Schaufeli vd. (2006) tarafından geliştrilen 2 boyutlu 17 maddeli ölçek, Schaufeli vd. (2009b) tarafından yapılan çalışmada kısaltılarak yine iki boyutlu ancak 10 ifadeli olacak şekilde yeniden düzenlenmiştir. Ölçekte çalışanların işkoliklik düzeyleri "Iş̧ yerindeki arkadaşlarım çalışmayı bıraktığında bile ben kendimi çalışmaya devam ederken bulurum" (aşırı çalışma boyutu) veya "Yaptığım bir işten hoşlanmasam bile sıkı çalışmak benim için önemlidir" (zorunlu çalışma boyutu) gibi ifadelerle ölçülmeye çalışılmıştır.

iş-yaşam dengesi: Çalışanların iş-yaşam dengesi algısının ölçümü için Brough vd. (2014) tarafından geliştirilen 4 ifade ve tek boyuttan oluşan ölçek kullanılmıştır. Katılımcıların iş-yaşam dengesi algısı "işsimde geçirdiğim zaman ile iş dışı faaliyetlerim için sahip olduğum zaman arasında iyi bir denge var" gibi ifadelerle ölçülmeye çalışılmıştır.

Yaşam tatmini: Çalışmada yaşam tatmininin ölçümünde Diener vd. (1985) tarafından geliştirilen 5 ifadeli ölçek kullanılmıştır. Ölçeğin Türkçe uyarlamasını yapan Dağlı ve Baysal (2016) ölçeğin Cronbach Alfa değerini 0,88 olarak elde etmişlerdir. Yaşam tatminin ölçümünde "Birçok yönden yaşamım idealimdekine yakındır" gibi ifadeler kullanılmıştır.

Duygusal bağlıık: Çalışanların örgüte olan duygusal bağ|ılıkları Meyer ve Allen tarafından geliştirilen 3 boyutlu örgütsel bağ|ılık ölçeğinin duygusal bağ|ı।ık boyutunu içeren 6 ifadeli ölçek kullanılarak ölçülmüştür. 
Duygusal bağlııı ölçeğinde "Kariyerimin geri kalan kısmını bu örgütte geçirmek beni mutlu eder" şeklinde ifadeler yer almaktadır.

\section{Bulgular}

\section{1. Ölçeklere İlişkin Geçerlilik ve Güvenirlik Bulguları}

Yapılan araştırma kapsamında kullanılan ölçeklerin yapısal geçerliği açımlayıcı ve doğrulayıcı faktör analizi ile ortaya konulmuştur. Araştırma kapsamında ilk olarak kullanılan ölçeklerin faktör yapılarını incelemek amacıyla açımlayıcı faktör analizi yapılmıştır. Açımlayıcı faktör analizi yapmadan önce veri setinin faktör analizi için uygun olup olmadığını belirlemek amacıyla yapılan Kaiser-Meyer-Olkin örneklem uygunluğu testi (KMO) değeri 0,89 olup bu değer çok iyi düzeyde örneklem uygunluğunu (Gürbüz ve Şahin, 2017: 317) ifade etmektedir. Bunun yanı sıra, yapılan Bartlett'in küresellik testi sonuçlarının anlamlı $\left(\chi^{2}=4437,63\right.$, $p<0,01)$ olduğu tespit edilmiştir. Bu doğrultuda mevcut veri seti çoklu normal dağılımlı ana kütledir ve faktör analizi için uygundur. Temel bileşenler yöntemi ve varimax döndürme yöntemi kullanılarak gerçekleştirilen faktör analizi sonucunda 5 faktörlü bir yapı ortaya çıkmıştır. Faktörlerin varyansı açıklama oranı ise \%69,55 olarak tespit edilmiştir. Ölçeklerde yer alan ifadelerin faktör yükleri 0,59 ile 0,86 arasında değişen değerler almıştır.

Açımlayıcı faktör analizi sonuçları doğrultusunda ortaya çıkan beş faktörlü yapının elde edilen verilerle uyumlu olup olmadığı doğrulayıcı faktör analizi (DFA) kullanılarak incelenmiştir. Açımlayıcı faktör analizinde işkolikliğin iki boyutlu yapısı ortaya konulduğu için bu değişken modelde 2. düzey DFA ile değerlendirilmiştir. En yüksek olabilirlik (Maksimum Likelihood) kestirim yöntemi kullanılarak gerçekleştirilen DFA sonucu elde edilen uyum iyiliği değerleri Tablo 2'de yer almaktadır. Elde edilen model uyum iyiliği değerleri, ölçüm modelinin iyi düzeyde uyum sağladığını ortaya koymaktadır (Gürbüz ve Şahin, 2017: 343).

Tablo 2. Doğrulayıcı Faktör Analizi Uyum İyiliği Değerleri

\begin{tabular}{|c|c|c|c|c|}
\hline \multirow{2}{*}{ İndeks Adı } & \multicolumn{2}{|c|}{ Eşik Değer } & \multirow{2}{*}{ Ölçek Değeri } & \multirow{2}{*}{$\begin{array}{l}\text { Uyum } \\
\text { Durumu }\end{array}$} \\
\hline & İyi Uyum & Kabul Edilebilir & & \\
\hline$X^{2} / d f$ & $\leq 3$ & $\leq 4-5$ & 1,73 & İyi Uyum \\
\hline GFI & $\geq 0,90$ & $\geq 0,89-0,85$ & 0,88 & Kabul Edilebilir \\
\hline CFI & $\geq 0,95$ & $\geq 0,90$ & 0,95 & İyi Uyum \\
\hline RMSEA & $\leq 0,05$ & $\leq 0,06-0,08$ & 0,05 & İyi Uyum \\
\hline
\end{tabular}

Çalışmada kullanılan ölçeklerde maddelerin birbirleriyle tutarlı olup olmadığını ve söz konusu kavramı ölçüp ölçmediğini belirlemek (Cronbach, 1951) amacıyla Cronbach Alfa değerlerine bakılmıştır. Ölçme aracına göre değişmekle birlikte önerilen en düşük Cronbach Alfa katsayısı 0,70 olarak belirlenmektedir (Panayides, 2013, s.689). Buna göre işkoliklik ölçeğinin Cronbach Alfa değeri 0,88, iş-aile dengesi ölçeğinin 0,91, yaşam tatmininin 0,92 ve duygusal bağlılık ölçeğinin ise 0,90 olarak belirlenmiştir (Tablo 3). Dolayısıyla elde edilen katsayıların tamamının 0,70'in üzerinde olması ölçeğin iç tutarlıığının sağlandığını ortaya koymaktadır.

İşkoliklik ile çalışanların iş-yaşam dengesi algıları, örgüte duygusal bağlıık ve yaşam tatmin düzeyleri arasındaki ilişkiyi belirlemek üzere korelasyon analizi gerçekleştirilmiş ve değişkenlere ait Pearson korelasyon katsayıları Tablo 3'te verilmiştir. 
Tablo 3. Değişkenlere Ait Ortalama, Standart Sapma ile Cronbach Alfa Değerleri ve Değişkenler Arasındaki Korelasyon Katsayıları

\begin{tabular}{lccccccc}
\hline & Ort. & ss & $\boldsymbol{\alpha}$ & işsoliklik & $\begin{array}{c}\text { isş-Yaşam } \\
\text { Dengesi }\end{array}$ & $\begin{array}{c}\text { Yaşam } \\
\text { Tatmini }\end{array}$ & $\begin{array}{c}\text { Duygusal } \\
\text { Bağlıık }\end{array}$ \\
\hline (1) Işsoliklik & 3,32 & 0,72 & 0,88 & 1 & & & \\
(2) Iş-Yaşam Dengesi & 2,90 & 0,84 & 0,91 & $-0,311^{* *}$ & 1 & & \\
(3) Yaşam Tatmini & 2,87 & 0,86 & 0,92 & $-0,309^{* *}$ & $0,448^{* *}$ & 1 & \\
(4) Duygusal Bağılıık & 3,05 & 0,73 & 0,90 & $-0,334^{* *}$ & $0,450^{* *}$ & $0,501^{* *}$ & 1 \\
\hline
\end{tabular}

${ }^{* *} \mathrm{p}<0,01,{ }^{\alpha}$ Cronbach Alfa Katsayısı

Ede edilen sonuçlara göre, katılımcıların işkolik davranış sergileme düzeyleri ile iş-yaşam dengesi algıları $(r=-0,311, p<0,01)$, yaşam tatmini $(r=-0,309, p<0,01)$ ve duygusal bağlılık $(r=0,334, p<0,01)$ düzeyleri arasında istatistiksel olarak anlamlı ve negatif yönlü ilişki bulunduğu belirlenmiştir. Buna göre işkolik çalışanların iş-yaşam dengeleri bozulmakta, duygusal bağlılıkları ve yaşam tatminleri azalmaktadır. Benzer şekilde, iş-yaşam dengesi ile duygusal bağlılık $(r=0,448, p<0,01)$ ve yaşam tatmini $(r=0,450, p<0,01)$ arasında ise pozitif doğrusal bir ilişki olduğu ortaya konulmuştur. Buna göre, çalışanların iş ve iş dışı yaşamları arasında denge olduğunu algılaması duygusal bağlılık ve yaşam tatmini gibi çalışan tutumlarını olumlu etkilemektedir.

\subsection{Yapısal Eşitlik Modeline ílişkin Bulgular}

Ölçme modelinin doğrulanmasından sonra araştırma kapsamında geliştirilen hipotezlerin test edilmesi için Yapısal Eşitlik Modeli (YEM) kullanılmıştır. Araştırma kapsamında kurulan modele ilişkin uyum iyiliği değerleri $(\chi 2 / \mathrm{sd}=1,80 ; \mathrm{p}<0,01 ; \mathrm{GFI}=0,87 ; \mathrm{CFI}=0,95 ; \mathrm{RMSEA}=0,06)$ modelin iyi uyum sağladığına işaret etmektedir. Yapılan analize ilişkin sonuçlar Şekil 2'de yer almaktadır.

Şekil 2. Yapısal Model ve Standartlaştırılmış Yol Katsayıları

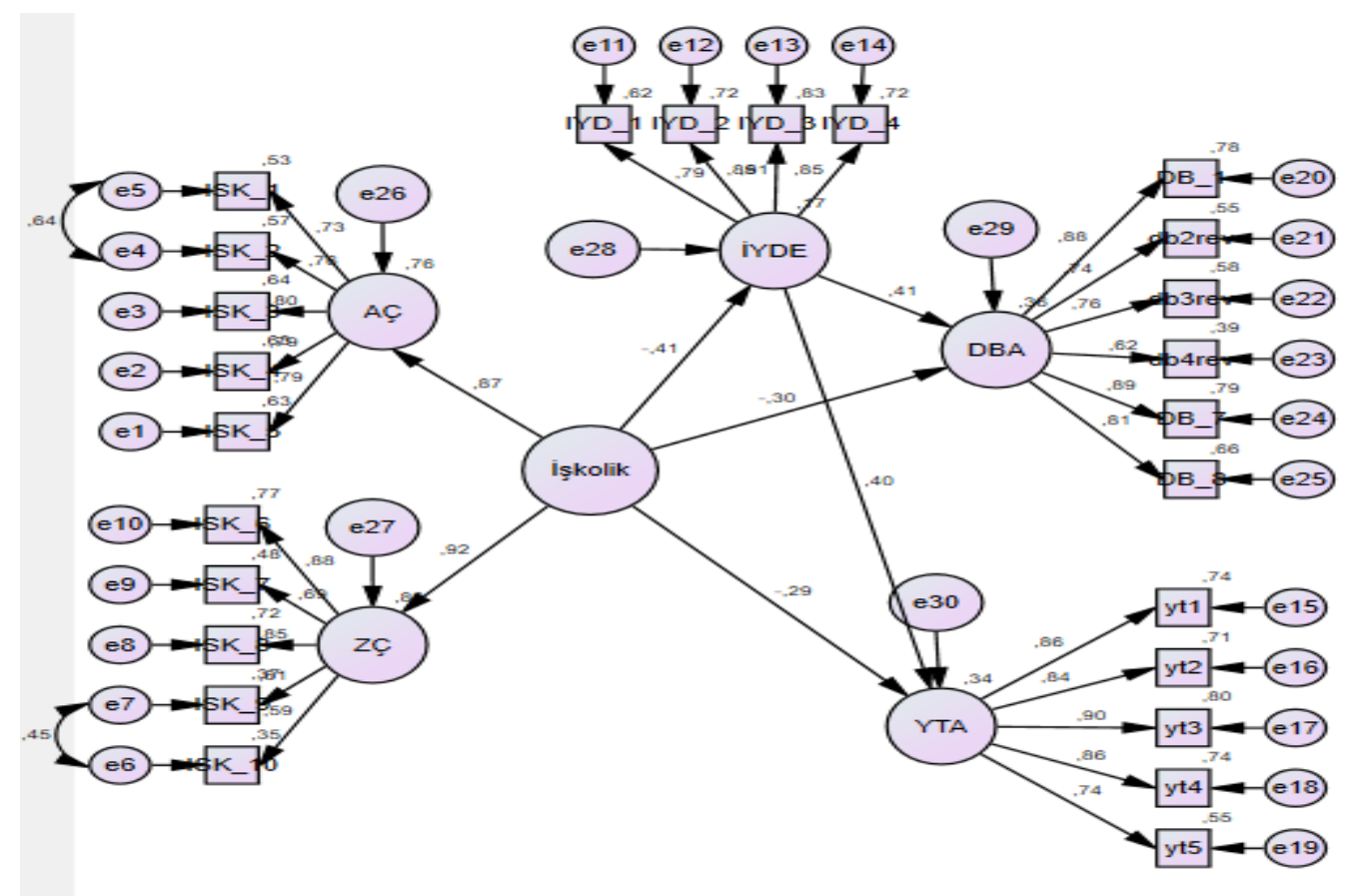


Şekil 2'de yer alan değerlere göre, işkolikliğin, iş-yaşam dengesi, yaşam tatmini ve duygusal bağlıık üzerinde negatif yönlü etkisi olduğu görülmektedir. Buna göre işkoliklik ile iş-yaşam dengesi ve yaşam tatmini arasında negatif ilişki olduğu yönündeki $\mathrm{H}_{1}$ ve $\mathrm{H}_{2}$ hipotezleri desteklenirken, işkolikliğin duygusal bağılıık ile pozitif ilişkili olduğuna ilişkin geliştirilen $\mathrm{H}_{3}$ hipotezi reddedilmiştir. Ayrıca iş-yaşam dengesinin yaşam tatmini ve duygusal bağlılık üzerinde pozitif yönlü etkisi olduğunu öne süren $\mathrm{H}_{4}$ ve $\mathrm{H}_{5}$ hipotezlerinin desteklendiği görülmektedir. Yapılan yol analizi ile işkoliklik, iş-yaşam dengesi, yaşam tatmini ve duygusal bağııık arasındaki doğrudan ilişkilerin yanı sıra dolaylı etkiler de ortaya konulmuştur.

Bootstrap yöntemiyle gerçekleştirilen analiz sonucu ortaya çıkan değişkenler arasındaki dolaylı etkiler Tablo 4'te yer almaktadır.

Tablo 4. Değişkenler Arasındaki Doğrudan ve Dolaylı Etkiler

\begin{tabular}{lccc}
\hline Etki & Doğrudan Etki & Dolaylı Etki & Toplam Etki \\
\hline iSK $\rightarrow$ iYD & $-0,414^{* *}$ & & \\
\hline iSK $\rightarrow$ YT & $-0,291^{* *}$ & & $-0,456^{* *}$ \\
\hline iSK $\rightarrow$ DB & $-0,301^{* *}$ & & $-0,469^{* *}$ \\
\hline iYD $\rightarrow$ YT & $0,397^{* *}$ & & $0,407^{* *}$ \\
\hline iYD $\rightarrow$ DB & $0,407^{* *}$ & & $0,397^{* *}$ \\
\hline iSK $\rightarrow$ iYD $\rightarrow$ YT & & $-0,164^{* *}$ & \\
\hline iSK $\rightarrow$ iYD $\rightarrow$ DB & & $-0,169^{* *}$ & \\
\hline${ }^{*} p<0,05,{ }^{* *} p<0,01$ & &
\end{tabular}

Elde edilen bulgulara göre işkolikliğin yaşam tatminine etkisinde iş-yaşam dengesinin aracılık etkisi olduğuna dair geliştirilen $\mathrm{H}_{6}$ hipotezi $(\beta=-0,164 * *(0,048)$, \%95GA BCA $=[-0,277--0,083])$ ile işkolikliğin duygusal bağlılığa etkisinde iş-yaşam dengesinin aracılık etkisi olduğuna dair geliştirilen $\mathrm{H}_{7}$ hipotezinin ( $\beta=$ $0,169 * *(0,049), \% 95 G A B C A=[-0,286--0,090])$ desteklendiği görülmektedir.

\section{Tartışma ve Sonuç}

Aşırı derecede sıkı çalışma eğilimi ve içten gelen bir dürtüyle çalışmaya takıntılı olma olarak tanımlanan (van Beek vd., 2011, s.469) işkoliklik, doğası gereği hem örgütler hem de çalışanlar açısından "kötü" bir durum olarak kabul edilmektedir. Çalışanlar işe daha fazla kendilerini kaptırdıkça, iş ve iş dışı yaşamlarında üstlenmiş oldukları rollerin gereklerini yerine getirememekte, yaşam kaliteleri düşmekte ve zamanla fiziksel ve ruhsal sağlıkları bozulabilmektedir. Ayrıca bir bağımlılık olarak nitelendirilen işkoliklik örgütün etkinliğini olumsuz etkileyen çalışan tutumlarına da yol açmaktadır. Buna göre, dışsal faktörlerden ziyade güçlü bir içsel dürtü tarafından motive edilen işkoliklik iş tatmini ile çalışan pe8rformansını olumsuz etkilerken, tükenmişlik ve strese neden olmaktadır (Schaufeli vd., 2008).

Bu çalışma ile çalışanların tutum ve davranışları ile örgüt üzerinde önemli etkileri olan işkolikliğin, işyaşam dengesi, duygusal bağlılık ve yaşam tatmini üzerindeki etkisi ve işkoliklik ile duygusal bağlılık ve yaşam tatmini ilişkisinde iş-yaşam dengesinin rolünün ortaya konulması amaçlanmıştır. Bu doğrultuda gerçekleştirilen çalışma sonucu elde edilen bulgular, çalışanların işe daha fazla kendilerini kaptırmaya başladıkça (işkoliklik), iş ve kişisel yaşamın taleplerini dengeleme yeteneklerinin giderek azaldığını ve iş-yaşam dengelerinin bozulduğunu ortaya koymaktadır. Benzer şekilde, işkolikliğin çalışanların genel yaşam tatminlerini ve örgüte karşı duygusal bağılıklarını olumsuz etkilediği yapılan çalışma sonucu ortaya konulmuştur. Daha önce işkoliklikle ilgili yapılmış olan çalışmaların (Aziz vd., 2010; Aziz ve Cunningham, 2008; Aziz ve Zickar, 2006; Pekdemir ve Koçoğlu, 2014; Vitiello vd., 2016) bulguları işkoliklik ile iş-yaşam dengesi ve yaşam tatmini arasındaki ilişkiye yönelik ortaya konulan bu sonuçları destekler niteliktedir.

Ancak işkoliklik ve duygusal bağlıık ile ilgili elde edilen sonuç literatürde daha önce yapılmış olan çalışmaların (Arsezen ve Kılıçarslan, 2017; Rakhshanimehr ve Jenaabadi, 2015) sonuçlarıyla örtüşmemektedir. Daha önce de belirtildiği gibi eğer birey yalnızca başarı elde etme güdüsüyle işkolik davranış sergiliyorsa, 
işkoliklik iş tatmini ve örgütsel bağlılık gibi çalışan tutumlarıyla pozitif ilişkili olmaktadır. Ancak birey çalışmak zorunda olduğunu hissettiği için işkolik davranış sergiliyorsa bu durumda işkoliklik çalışan tutumlarını olumsuz etkilemektedir (Scott vd., 1997: 300-306). Dolayısıyla işkoliklik ile duygusal bağlılık arasında elde edilen bu sonuçla önceki çalışmaların bulguları arasındaki farklılı̆ın çalışanların işkolik olma nedenlerine dayandığı, yani anketi cevaplayan katılımcıların çoğunun çalışmaya zorunlu olduklarını düşündükleri ya da çalışma takıntısı olduğu için işkolik davranış sergiledikleri, bunun da duygusal bağıııklarını olumsuz etkilediği düşünülmektedir. Öte yandan işkolik çalışanların, örgütlerine bağlı olmaktan ziyade kariyerine ve işlerine daha fazla bağlı oldukları tespit edilmiştir (Burke, 2006: 176). Başka bir deyişle, işkoliklerin çalışmaya bağlı olmaları örgütlerine de duygusal olarak bağlı olmalarını gerektirmez. Dolayısıyla, bazı işkolik insanlar kendilerini örgütleriyle güçlü bir şekilde özdeşleştirirken, bazıları yalnızca işlerine bağlı olabilmektedir (Aziz vd., 2013: 80).

Çalışmada elde edilen diğer bir sonuç da çalışanların iş ve iş dışı yaşamlarında minimum sevide rol çatışması yaşaması yani iş ve iş dışı yaşamının dengede olması durumunda çalıştığı örgüte karşı duygusal bağlılı̆̆ının ve yaşam tatminin artacağıdır. Geçmişte yapılmış olan çalışmaların (Haar, Russo, Suñe ve OllierMalaterre, 2014; Gorsy ve Panwar, 2016; Azeez vd., 2017; Sakthivel ve Jayakrishnan, 2018) sonuçları da bu sonuçları desteklemektedir. Çalışmada bu doğrudan ilişkilerin yanı sıra işkolikliğin yaşam tatmini ve duygusal bağlııığa olan etkisinde iş-yaşam dengesinin aracılık rolü de ele alınmıştır. Buna göre işkoliklik ile yaşam tatmini ve duygusal bağlııı arasındaki ilişkide iş-yaşam dengesinin kısmi aracılık etkisinin olduğu ortaya konulmuştur. Buna göre, işkolikliğin duygusal bağlılık ve yaşam tatmini üzerindeki etkisi iş-yaşam dengesinin aracılık etkisiyle birlikte azalmakta ancak tam olarak ortadan kalkmamaktadır. Bu sonuç, işkoliklik ile duygusal bağılık ve yaşam tatmini arasındaki ilişkilerde iş-yaşam dengesinin tek aracı değişken olmadığını, başka değişkenlerin de bu ilişkilerde aracılık rolünün bulunduğunu ortaya koymaktadır.

Elde edilen bulgular doğrultusunda, birçok araştırmacı tarafından olumsuz bir durum olarak değerlendirilen işkolikliğin, düşünülenin aksine örgütler ve bireyler açısından olumsuz sonuçlar doğurabildiği söylenebilmektedir. Hatta işkolik çalışanlar örgütler için potansiyel bir tehlike olabilmekte, çalışma ortamında stres oluşmasına, diğer çalışanların morallerinin bozulmasına sebep olarak bütün çalışma düzenini bozabilmektedirler. Ortaya çıkabilecek bu tür olumsuz sonuçları önleyebilmek için yöneticiler bu çalışanları kontrol edebilmenin yolunu bulmalıdırlar. Örneğin, işkolik çalışanları işlerinin bir kısmını başkalarına devretmeleri konusunda cesaretlendirme, bu çalışanlara mola vermeleri ve işten ayrılmaları için belirli bir zaman verme gibi uygulamalarla çalışanın aşırı çalışma isteği kontrol edilebilecektir. Böylelikle çalışanın, diğer aktivitelerden uzak kalıp çalışmaya aşırı düşkün olmasının önüne geçilerek ve iş ile iş dışı yaşamına dengeli bir şekilde vakit ayırması sağlanarak, olumlu tutum ve davranışların ortaya çıkması ve dolayısıyla da çalışanın kendisinden beklenen performansı göstererek örgüte katkısının artması mümkün olabilecektir. Ayrıca örgütsel bağııık ve yaşam tatmini gibi olumlu çalışan tutum ve davranışlarını arttırabilmek adına çalışanın iş dışı yaşamına da vakit ayırabileceği bir çalışma düzeni oluşturularak çalışanda iş-yaşam dengesi algısının oluşması sağlanmalıdır.

Her çalışmada olduğu gibi bu çalışma da bir takım kısıtlar içermektedir. İşkolikliğin çalışan tutum ve davranışları üzerindeki etkisi işkolik davranışın türüne bağlı olarak değişebilmektedir. Ancak bu çalışmada bu davranışın türünün belirlenememiş olması çalışmanın en önemli kısıtı olarak görülmektedir. Bundan sonra yapılacak çalışmalarda işkolik davranışın türünün belirlenmesi sonuçları daha iyi değerlendirebilme imkanı verecektir.

Çalışmanın tek sektörde yapılmış olması araştırmanın önemli bir kısıtıdır. Bu nedenle farklı sektörlerde yapılacak araştırmalardan farklı sonuçlar elde edilebileceği düşünülerek bundan sonra farklı sektörlerde gerçekleştirilecek çalışmalarla sektörler arasında karşılaştırma yapabilmek mümkün olabilecektir.

Yapılan çalışmada, işkoliklik ile duygusal bağlıık ve yaşam tatmini arasındaki ilişkilerde yalnızca işyaşam dengesinin aracı değişken rolü incelenmiştir. Ancak elde edilen bulgular bu ilişkilerde iş-yaşam dengesinin tek aracı değişken olmadığını, başka değişkenlerin de bu ilişkilerde aracılık rolünün bulunduğunu ortaya koymuştur. Dolayısıyla bundan sonra yapılacak çalışmalarda bu değişkenler arasındaki ilişkiyi 
etkileyebilecek değişkenlerin neler olabileceğini ortaya koyabilmek adına farklı değişkenlerle kurulacak modellerin test edilmesi önerilmektedir.

Çalışanın diğer bir kısıtı kesitsel bir çalışma olmasıdır. Gelecekte yapılacak çalışmalarda söz konusu değişkenlerin belirli zaman aralı̆ında tekrarlanan bir şekilde ölçülmesi farklı zaman dilimlerinde ortaya çıkabilecek farklılıkları da ortaya koyabilmek adına faydalı olacaktır. İçermiş olduğu tüm bu kısıtlara rağmen, çalışmanın işkolikliğin çalışanların iş-yaşam dengesi algısı üzerindeki etkisini belirleyerek ve bu iki değişkenin birlikte etkilediği çalışan tutumlarını ortaya koyarak literatüre ve söz konusu ilişkilerin çalışma yaşamında değerlendirilerek olumsuzlukların ortadan kaldırılmasıyla da uygulamaya katkı sağlaması beklenmektedir.

\section{Son Notlar}

1. Bu makale 28-30 Kasım 2018 tarihlerinde gerçekleştirilen ICOAEF'18 IV. International Conference on Applied Economics and Finance'de sunulan bildirinin genişletilmiş halidir.

\section{Kaynaklar}

Anand, M., \& Arora, D. (2009). Burnout, life satisfaction and quality of life among executives of multi national companies. Journal of the Indian Academy of Applied Psychology, 35(1), 159-164.

Arsezen, P., \& Kilıçarslan, U. (2017). Relationship between workaholic behavior and job satisfaction of tourism industry employees: Intermadiary role of emotional commitment to the organization. Journal of Social and Humanities Sciences Research, 4(12), 867-882.

Azeez, R. O., Fapohunda, T. M., \& Jayeoba, F. I. (2017). Work-life balance and organisational commitment: Perceptions of working postgraduate students. BVIMSR's Journal of Management Research, 9(2), 178-188.

Aziz, S., Adkins, C. T., Walker, A. G., \& Wuensch, K. L. (2010). Workaholism and work-life imbalance: Does cultural origin influence the relationship? International Journal of Psychology, 45(1), 72-79.

Aziz, J., \& Cunningham, J. (2008). Workaholism, work stress, work-life imbalance: Exploring gender's role. Gender in Management: An International Journal, 23(8), 553-566.

Aziz, S., Uhrich, B., Wuensch, K. L., \& Swords, B. (2013). The workaholism analysis questionnaire: Emphasizing work-life imbalance and addiction in the measurement of workaholism. Institute of Behavioral and Applied Management, 14(2), 71-86.

Aziz, S., \& Zickar, M. J. (2006). A cluster analysis investigation of workaholism as a syndrome. Journal of Occupational Health Psychology, 11(1), 52-62.

Becker, H. S. (1960). Notes on the concept of commitment. American Journal of Sociology, 66, 32-40.

Brough, P., Timms, C., O'Driscoll, M. P., Kalliath, T., Siu, O., Sit, C., \& Lo, D. (2014). Work-life balance: A longitudinal evaluation of a new measure across Australia and New Zealand workers. The International Journal of Human Resource Management, 25, 19, 2724-2744.

Buelens, M., \& Poelmans, S. A. Y. (2004). Enriching the Spence and Robbins' typology of workaholism: Demographic, motivational and organizational correlates. Journal of Organizational Change Management, 17(5), 440-458

Bulgurcu Gürel, E. B., \& Altunoğlu, A. E. (2016). İ̧̧koliklik, iş stresi ve yaşam doyumu arasındaki ilişkilerin incelenmesi: Muğla ilinde bir araştırma. Ulus/ararası Sosyal Araştırmalar Dergisi, 9(42), 1431-1438.

Burke, R. J. (2006). Workaholic types: It's not how hard you work but why and how you work hard. Içinde Burke, R. J. (Ed.), Research companion to working time and work addiction (pp. 173-192). Northapton, MA: Edward Elgar Publishing.

Burke, R. J., \& MacDermid, G. (1999). Are workaholics job satisfied and successful in their careers? Career Development International, 4(5), 277-282.

Clark, S. C. (2001). Work cultures and work/family balance. Journal of Vocational Behavior, 58, 348-365.

Cohen, A. (1993). Age and tenure in relation to organizational commitment: A meta-analysis. Basic And Applied Social Psychology, 14(2), 143-159.

Cronbach, L. J. 1951. Coefficient alpha and the internal structure of tests. Psychometrika, 16(3), 297-334. 
Demerouti, E., Bakker, A. B., Nachreiner, F., \& Schaufeli, W. B. (2000). A model of burnout and life satisfaction amongst nurses. Journal of Advanced Nursing, 32(2), 454-464.

Diener, E., Emmons, R. A., Larsen, R. J., \& Grifin, S. (1985). The satisfaction with life scale. Journal of Personality Assessment, 49(1), 71-75.

Dixon, M. A., \& Sagas, M. (2007). The relationship between organizational support, work-family conflict, and the job-life satisfaction of university coaches. Research Quarterly for Exercise and Sport, 78(3), 236-247.

Ghosh, S., \& Swamy, D. R. (2014). A literature review on organizational commitment - A comprehensive summary. Int. Journal of Engineering Research and Applications, 4(12), 4-14.

Gorsy, C., \& Panwar, N. (2016). Work-life balance, life satisfaction and personality traits among teaching professionals. International Journal in Management and Social Science, 4(2), 98-105.

Greenhaus, J. H., Collins, K. M., \& Shaw, J. D. (2003). The relation between work-family balance and quality of life. Journal of Vocational Behavior, 63, 510-531.

Gürbüz, S., \& Şahin, F. (2017). Sosyal bilimlerde araştırma yöntemleri felsefe, yöntem, analiz (4. Baskı). Ankara: Seçkin Yayıncilık.

Haar, J. M. (2013). Testing a new measure of work-life balance: a study of parent and non-parent employees from New Zealand. The International Journal of Human Resource Management, 24(17), 3305-3324.

Haar, J. M., Russo, M., Suñe, A., \& Ollier-Malaterre, A. (2014). Outcomes of work-life balance on job satisfaction, life satisfaction and mental health: A study across seven cultures. Journal of Vocational Behavior, 85, 361-373.

Hayes, N., \& Joseph, S. (2003). Big 5 correlates of three measures of subjective well-being. Personality and Individual Differences, 34, 723-727.

Heller, D., Judge, T. A., \& Watson, D. (2002). The confounding role of personality and trait affectivity in the relationship between job and life satisfaction. Journal of Organizational Behavior, 2(7), 815-835.

Iverson, R. D., \& Maguire, C. (2000). The Relationship between job and life satisfaction: Evidence from a Remote Mining Community. Human Relations. 53(6), 807-839.

İplik, E. (2017). Yabancı uyruklu akademisyenlerin birey-çevre uyumu: İşe yönelik tutumlarda kültürel adaptasyonun rolü. Çukurova Üniversitesi, Yayınlanmamış Doktora Tezi. Adana.

Kessler, E. H. (2013). Encyclopedia of management theory. London: Sage Publications.

Levy, D. V. (2015). Effects of workaholism on satisfaction among US managerial and professional women. Gender in Management: An International Journal, 30(8), 635-651.

Machlowitz, M. (1978). Determining the effects of workaholism. Yale University, Doctoral dissertation.

Melèndez, J. C., Tomás, J. M., Oliver, A., \& Navarro, E. (2009). Psychological and physical dimensions explaining life satisfaction among the elderly: A structural model examination. Archives of Gerontology and Geriatrics, 48, 291295.

Meyer, J. P., \& Allen, N. J. (1991). A three-component conceptualization of organizational commitment. Human Resources Management Review, 1, 61-89.

Mirza, C. S. (2012). Positive and negative workaholism. University of Houston, Unpublished Ph.D. dissertation.

Mudrack, P. E. (2006). Understanding workaholism: The case for behavioral tendencies. Içinde Burke, R. J. (Ed.), Research companion to working time and work addiction (pp. 108-128). Northapton, MA: Edward Elgar Publishing.

Near, J. P. (1984). Relationships between job satisfaction and life satisfaction: test of a causal model. Social Indicators Research, 15(4), 351-367.

Ölçer, F. (2005). İşkoliklik üzerine bir araştırma. SÜ iiBF Sosyal ve Ekonomik Araştırmalar Dergisi, 5(9), $122-144$.

Panayides, P. (2013). Coefficient alpha: Interpret with caution. Europe's Journal of Psychology, 9(4), 687-696.

Pasupuleti, S., Allen, R. I., Lambert, E. G., \& Cluse-Tolar, T. (2009). The Impact of work stressors on the life satisfaction of social service workers: A preliminary study. Administration in Social Work, 33(3), 319-339.

Peiperl, M., \& Jones, B. (2001). Workaholics and overworkers: Productivity or pathology? Group \& Organization Management, 26(3), 369-393.

Pekdemir, I., \& Koçoğlu, M. (2014). İşkoliklik ile iş yaşam dengesi arasındaki ilişkide kişilik özelliklerinin aracılık rolü üzerine bir araştırma. AiBÜ Sosyal Bilimler Enstitüsü Dergisi, 14(1), 309-337. 
Porter, G. (1996). Organizational impact of workaholism: Suggestions for researching the negative outcomes of excessive work. Journal of Occupational Health Psychology, 1, 70-84.

Powell, D. M., \& Meyer, J. P. (2004). Side-bet theory and the three-component model of organizational commitment. Journal of Vocational Behavior, 65, 157-177.

Premeaux, S. F., Adkins, C. L., \& Mossholder, K. W. (2007). Balancing work and family: A field study of multi-dimensional, multi-role work-family conflict. Journal of Organizational Behavior, 28, 705-727.

Rakhshanimehr, F., \& Jenaabadi, H. (2015). Relationship of workaholism with teachers' organizational commitment and organizational citizenship behavior. Psychology, 6, 1469-1477.

Robinson, B. E. (2007). Chained to the desk: A guidebook for workaholics, their partners and children, and the clinicians who treat them (2nd ed.). New York, NY, US: New York University Press.

Sakthivel, D., \& Jayakrishnan, J. (2018). Work life balance and organizational commitment for nurses. Asian Journal of Business and Management Sciences, 2(5), 1-6.

Saltzstein, A. L., Ting, Y., \& Saltzstein, G. H. (2001). Work-family balance and job satisfaction: The impact of familyfriendly policies on attitudes of federal government employees. Public Administration Review, 61(4), 452-467.

Sayğan, F. N. (2011) Relationship between affective commitment and organizational silence: A conceptual discussion. International Journal of Social Sciences And Humanity Studies, 3(2), 219-227.

Schaufeli, W. B., Bakker, A. B., van der Heijden, F. M. M. A., \& Prins, J. T. (2009a). Workaholism, burnout and well-being among junior doctors: The mediating role of role conflict. Work \& Stress, 23, 155-172.

Schaufeli, W. B., Shimazu, A., \& Taris, T. W. (2009b). Being driven to work excessively hard: The evaluation of a twofactor measure of workaholism in the Netherlands and Japan. Cross-Cultural Research, 43, 320-348.4

Schaufeli, W. B., Taris, T. W., \& van Rhenen, W. (2008). Workaholism, burnout, and work engagement: Three of a kind or three different kinds of employee well-being? Applied Psychology: An International Review, 57(2), $173-203$.

Schaufeli, W. B., Taris, T. W., \& Bakker, A. (2006). Dr. Jekyll and Mr. Hide: On the differences between work engagement and workaholism. İçinde Burke, R. (Ed.), Research companion to working time and work addiction (pp. 193-217). Northampton, MA: Edward Elgar.

Schimmack, U., Diener, E., \& Oishi, S. (2002). Life-satisfaction is a momentary judgment and a stable personality characteristic: The use of chronically accessible and stable sources. Journal of Personality, 70(3), 345-384.

Scott, K. S., Moore, K. S., \& Miceli, M. P. (1997). An exploration of the meaning and consequences of workaholism. Human Relations, 50, 287-314.

Shin, D. C., \& Johnson, D. M. (1978). Avowed happiness as an overall assessment of the quality of life. Social Indicators Research, 5, 475-492.

Spence, J. T., \& Robbins, A. S. (1992). Workaholism: Definition, measurement, and preliminary results. Journal of Personality Assessment, 58, 160-178.

Taris, T. W., Schaufeli, W. B., \& Verhoeven, L. C. (2005). Internal and external validation of the Dutch Work Addiction Risk Test: Implications for jobs and non-work conflict. Applied Psychology: An international Review, 54, 37-60.

Van Beek, I., Taris, T. W., \& Schaufeli, W. B. (2011). Workaholic and work engaged employees: Dead ringers or worlds apart? Journal of Occupational Health Psychology, 16(4), 468-482.

Vanaki, Z., \& Vagharseyyedin, S. A. (2009). Organizational commitment, work environment conditions, and life satisfaction among Iranian nurses. Nursing and Health Sciences, 11, 404-409.

Vitiello, K., Aziz, S., \& Wuensch, K. L. (2016). Workaholism and authenticity: The role of life satisfaction. Journal of Behavioral and Applied Management, 17(2), 116-133.

Wasti, A. S. (2002). Affective and continuance commitment to the organization: Test of anintegrated model in the Turkish context. International Journal of Intercultural Relations, 26, 525-550.

Yüksel, H. (2014). The concept of workaholism as the extreme point in work engagement, its individual and organizational outcomes. Uluslararası Alanya işletme Fakültesi Dergisi, 6(2), 119-130. 
This Page Intentionally Left Blank 